\title{
Ortaokul Matematik Öğretmenleri Ölçme-Değerlendirmeyi Nasıl Yapıyor? Bir Durum Çalışması ${ }^{1}$
}

\section{How Middle School Mathematics Teachers Do Measurement and Assessment? A Case Study}

\author{
Fatih Önel ${ }^{2}$, Funda Dalkılınç ${ }^{3}$, Neslihan Özel ${ }^{4}$, Şule Deniz ${ }^{5}$, Tuğçe Balkaya ${ }^{6}$, Gamze Kurt Birel ${ }^{7}$
}

Anahtar Kelimeler
ölçme ve değerlendirme
ortaokul matematik
öğretmeni
yapılandırmacı yaklaşım
alternatif ölçme ve
değerlendirme

değerlendirme

Keywords
measurement and
assessment
middle school
mathematics teachers
constructivist approach
alternative
measurement and
assessment

\section{Başvuru Tarihi/Received}

11.12.2019

Kabul Tarihi /Accepted 25.02.2020

\begin{abstract}
Öz
Bu araştırmanın amacı, ortaokul matematik öğretmenlerinin yapılandırmacı yaklaşım çerçevesinde ölçme ve değerlendirme sürecini nasıl yaşadıklarını ve kullandıkları alternatif değerlendirme yöntemlerine olan farkındalıklarını incelemektir. Yapılandırmacı yaklaşım geleneksel ölçme-değerlendirmenin yerine alternatif ölçme-değerlendirme yaklaşımına vurgu yapmaktadır. Geleneksel ölçme-değerlendirme sürecinde öğrenci performansları anlık olarak değerlendirilir ve üst düzey hedef davranışları ölçmede yetersizdir (Şaşmaz Ören, Ormancı ve Evrekli, 2011). Öğrencilerin yeteneklerini ve bireysel performanslarını değerlendirmek için alternatif ölçme-değerlendirme yaklaşımlarına yönelmek gerekmektedir (Watt, 2005). Araştırma bir çoklu durum çalışması olup maksimum çeşitlilik örneklemi aracılığıyla beş ortaokul matematik öğretmeni belirlenmiştir. Temel veri toplama araçları görüşme, gözlem notları ve dokümanlardır. Durumlar karşılıklı analiz edildiğinde verinin üç ana başlık altında toplanabileceği görülmüştür. Bu başlıklar öğretmenlerin değerlendirme yapmaktaki amaçları, öğretmenlerin kendilerini ölçme-değerlendirme etkinliklerini yapma zorunluluğunda hissetmeleri ve tüm değerlendirme etkinlikleri sonunda öğrenciye verilecek nihai notu nasıl belirledikleri olmuştur. Araştırmanın bulgularına göre öğretmenlerin değerlendirme yapmalarının temel amaçları arasında öğrencilerin öğrenme eksiklerini belirlemek, öğretim sürecinin etkililiği hakkında bilgi edinmek ve velileri öğrenci hakkında bilgilendirmek olduğu görülmektedir. Katılımcıların tüm değerlendirme etkinlikleri sonunda öğrencilerin nihai notunu belirlerken yazılılar ve projelerden ders ve etkinliklere katılım puanlarından yararlandıkları görülmüştür. Öğretmenlerin yapılandırmacı yaklaşımı benimsediklerini, alternatif değerlendirme yöntemlerini hazırlama ve uygulamada zorlanmasa da değerlendirme aşamasında sınıf, okul, öğrenci ve veli profili gibi etkenlerden dolayı daha çok geleneksel ölçme-değerlendirme yöntemlerini kullandıkları görülmüştür. Alternatif değerlendirme yöntemlerini puanlama aşamasında sıkıntı çektikleri için bu konuda bilgilerinin yetersiz olduğu sonucuna varılmıştır. Yapılan görüşmelerde katılımcıların ölçme-değerlendirme yöntemleri konusunda açılacak seminer ve hizmet-içi eğitimlere istekli olmaları, bu alanda yapılacak araştırmalar için göz önünde bulundurulmalıdır.
\end{abstract}

\section{Abstract}

The aim of this study is to examine how middle school mathematics teachers experience the measurement and assessment process within the framework of the constructivist approach and their awareness of the alternative assessment methods they use. According to the general qualifications of teaching profession published by Ministry of National Education in 2017, the teacher should use process-oriented approach throughout the assessment process, prepare the assessment tools in accordance with the developmental characteristics of the students and rearrange the educational environment with the feedback obtained from their results. The study was a multiple case study and five middle school mathematics teachers were determined to be diverse in terms of age, gender, professional experience, and the central district where they work. Fundamental data collection tools are interview, observation notes and documents. The findings were analyzed through common themes and codes. Although the teachers adopt constructivist approach, it is observed that they use traditional methods of assessment because of the factors such as class, school, student and parent profiles in the assessment process, although they are not having difficulty to prepare and implement alternative assessment methods. It is concluded that their knowledge on this issue is insufficient because they have difficulty in scoring alternative assessment methods. In the interviews, the participants' willingness to attend seminars and in-service trainings on measurement and assessment methods should be considered for the research to be conducted in this area.

\footnotetext{
${ }^{1}$ Bu çalışma 4. Uluslararası Türk Bilgisayar ve Matematik Eğitimi Sempozyumu (TürkBilmat-4)'nda sunulan bildirinin genişletilmiş halidir.

${ }^{2}$ Mersin Üniversitesi, Eğitim Fakültesi, Matematik ve Fen Bilimleri Eğitimi Bölümü, Mersin, TÜRKiYE; https://orcid.org/0000-0002-0560-8141

${ }^{3}$ Mersin Üniversitesi, Eğitim Fakültesi, Matematik ve Fen Bilimleri Eğitimi Bölümü, Mersin, TÜRKiYE; https://orcid.org/0000-0002-5240-802X

${ }^{4}$ Mersin Üniversitesi, Eğitim Fakültesi, Matematik ve Fen Bilimleri Eğitimi Bölümü, Mersin, TÜRKiYE; https://orcid.org/0000-0002-3521-3909

${ }^{5}$ Mersin Üniversitesi, Eğitim Fakültesi, Matematik ve Fen Bilimleri Eğitimi Bölümü, Mersin, TÜRKiYE; https://orcid.org/0000-0002-3119-7403

${ }^{6}$ Mersin Üniversitesi, Eğitim Fakültesi, Matematik ve Fen Bilimleri Eğitimi Bölümü, Mersin, TÜRKiYE; https://orcid.org/0000-0002-0792-2740

${ }^{7}$ Mersin Üniversitesi, Eğitim Fakültesi, Matematik ve Fen Bilimleri Eğitimi Bölümü, Mersin, TÜRKiYE; https://orcid.org/0000-0002-4976-5069
} 


\section{Extended Abstract}

\section{Introduction}

The traditional assessment focuses on the repetition of what is learned and it usually ranks students; however, it is necessary to prefer to alternative assessment approaches to assess students' abilities and their performance (Watt, 2005). An alternative assessment approach is an approach that supports learning by giving feedback to students about their progress and deficiencies as well as grading, in contrast to the traditional approach whose sole purpose is to grade students (Karamustafaoğlu, Çağlak \& Meşeci, 2012). Therefore, alternative measurement and evaluation tools such as performance, portfolio, etc. are intertwined with real-life (McAlister, 2000). In the alternative assessment approach; self-evaluation, peer evaluation, joint evaluation, individual product files (portfolio), interviews, diaries, surveys, projects, concept maps and drama are recommended to be used (Mintah, 2003; Van de Walle, 2007).

Studies conducted show that teachers and prospective teachers from different branches are inadequate or perceive themselves as insufficient in terms of alternative assessment tools and therefore continue to use traditional assessment methods. Şaşmaz Ören, Ormancı, and Evrekli (2011) concluded that participants used alternative assessment and evaluation tools at the end of the course. This result was interpreted as the participants' training was carried out with a traditional measurement and evaluation approach. In the same study, it was stated that the teacher candidates' opinions would change when they reached enough information about alternative assessment and they were willing to use alternative assessment and assessment tools when they started their profession and they were aware that these instruments supported effective and permanent learning (Şaşmaz Ören, Ormanci, and Evrekli, 2011). In this study, by using the richness of qualitative data, how middle school mathematics teachers make assessment and evaluation and their perspectives are examined within the framework of the constructivist approach and the level of awareness of teachers about alternative assessment methods were also examined.

\section{Method}

The study was designed as a multiple case study. Participants are 5 different middle school mathematics teachers working in the central districts of Mersin province. Each participant is the 'unit of analysis' of this case study (Yin, 2017, p. 34). A maximum diversity sample was formed in order to identify the main themes used in purposeful sampling (Patton, 2014, p. 235). The main data collection tools used in this study were interviews, observations and documents. In the research, the content analysis technique was used. When the data collection tools (interview protocol and observation form) were prepared, possible themes and codes were determined by the research team. The collected data were transcribed verbatim and coded according to the themes and codes. This coding process was conducted by the researcher who interviewed each participant. After the completion of this process, the research team came together and examined how coherent their coding was.

\section{Result and Discussion}

When data analyzed holistically, the findings were organized under the three headings. The first one is the objectives of teachers in evaluating. We found that the main objectives of all teachers to evaluate are to determine students' learning deficiencies, to learn about the effectiveness of the teaching process and to inform parents about the student. It was noticed that some teachers are sensitive to their evaluations and therefore use a graded scoring key. The second heading is that the participants feel obliged to perform measurement and evaluation activities. We observed that teachers mostly used traditional assessment methods such as oral, written exam and project assignment due to the current examination system, the directives specified in the regulation and the decisions taken in the teachers' committee. Third one is how participants determine the final grade to be given to the student at the end of whole assessment process. We observed that all teachers used paper-pencil exams and projects as well as extra points in courses and activities when determining the final grade of the student. It was found that some teachers (Teacher A, C and E) did not want to give low grades and hence tend to make grades higher. This was attributed to the fact that grades were important because the education system was exam-oriented.

Teachers had a positive approach towards alternative assessment methods. However, it was concluded that teachers used traditional measurement and assessment practices more often in their classrooms. This finding coincides with Gelbal and Kelecioğlu's (2007) research that "it is understood that teachers prefer traditional methods in getting to know their students and determining their success levels" (p. 143). Teachers do not consider themselves sufficient in evaluation, especially in the preparation and implementation of alternative assessment and evaluation practices and they are willing to receive in-service training and develop themselves. As Göktaş and Arıbaş (2014) concluded that teachers wanted to receive applied training given by experts about alternative assessment and evaluation.

Participants in our study felt that they have to give high grades in the measurement process due to various reasons and they gave high grades to the students even if they did not deserve it. The reason for this is that teachers want to eliminate the perception that mathematics is a difficult and unsuccessful lesson and they want students to develop a positive attitude towards mathematics. Teachers point to the current examination and grading system as another reason for giving students higher grades than they deserve. Therefore, it can be seen that mathematics teachers working in public schools were required to use usch an assessment way for many reasons. We concluded that teachers' use of assessment and grading systems are inadequate in revealing the current achievement levels and learning deficiencies of the students. Besides, we observed that the revised 
mathematics program did not provide enough guidance to teachers in planning their measurement, and did not provide sufficient support to teachers about how to apply them although the program mentioned about the objectives of measurement and assessment. These findings are in line with the findings of Duru and Korkmaz (2010) that mathematics program do not have enough measurement tools to offer for mathematics teachers and that the existent assessment and evaluation practices recommended to teachers might not be applied in crowded classes. 
GiRiş

Davranışçı ve bilişsel yaklaşımların yerine yapılandırmacı yaklaşımın temel alınarak yenilendiği öğretim programlarında ölçmedeğerlendirme ilkeleri önemli bir paya sahiptir (Millî Eğitim Bakanlığı [MEB], 2018). Yapılandırmacı yaklaşımda bilginin öğrenci tarafından yapılandırıldığı kabul edilmektedir. Bu yaklaşımın bir gereği olarak öğretmen merkezli bir öğretimden uzaklaşılarak öğrenci merkezli öğretim yöntemi benimsenmekte; öğrenci-öğretmen ve öğrenci-öğrenci etkileşimine aile ve çevrenin de katılımı amaçlanmaktadır. Öğretim programlarındaki bu değişiklik derslerin içeriğinde, öğretim yöntemlerinde, kullanılan araç ve gereçlerle ölçme ve değerlendirme yöntemlerinde de değişikliklere neden olmuştur (Gelbal ve Kelecioğlu, 2007). Öğretim programının yanı sıra, MEB, yayınladığı İlköğretim Kurumları Yönetmeliği'nde ölçme-değerlendirmenin nasıl yapılması gerektiğine dair öğretmenleri yönlendirmektedir. Bu yönetmeliğe göre ölçme-değerlendirmenin amacı, öğrencileri elemek ya da sıralamak değil, öğrencinin başarısını, derslere ve sosyal etkinliklere katılımı ile bir bütün olarak değerlendirmektir (MEB, 2014). O halde, ölçme ve değerlendirme kavramlarının yapılandırmacı yaklaşım çerçevesinde nasıl ele alınacağı açıklanmalıdır. Ölçme bir değişkene ilişkin gözlemlerin sayı ve sembollerle ifade edilmesi olup, değerlendirme ise ölçme sonuçlarının bir ölçütle karşılaştırılarak bu sonuçlar hakkında karara varma işlemi olarak tanımlanmıştır (Turgut, 2011). Yenilenen programlar ölçme-değerlendirme açısından incelendiğinde; bireysel farklılıklar dikkate alınarak bütün öğrencileri kapsayan, tek tip bir ölçme ve değerlendirme yönteminden söz etmenin uygun olmayacağı, öğrencinin akademik gelişiminin tek bir yöntemle veya teknikle ölçülüp değerlendirilemeyeceği ve eğitimin sadece 'bilme (düşünce)' için değil, 'hissetme (duygu)' ve 'yapma (eylem)' için de verilmesi gerektiğinden, sadece bilişsel ölçmelerin yeterli kabul edilemeyeceği karşımıza çıkmaktadır (MEB, 2018).

Yapılandırmacı yaklaşım, öğretim programlarının önerdiği ölçme ve değerlendirme süreçlerini de güçlü bir şekilde etkilemiştir (Fourie ve Van Niekerk, 2001). Geleneksel ölçme ve değerlendirme, öğretim sürecinden ayrı ve ürün odaklıdır. Bu amaçla daha çok, çoktan seçmeli ve kısa cevaplı testlere, yazılı ve sözlü yoklamalara önem verilmektedir (Gelbal ve Kelecioğlu, 2007). Kalemkâğıt testleriyle bilgi aktarımına aşırı vurgu yapan geleneksel değerlendirme, öğrencilerin zaman içindeki performanslarının ve öğrenmelerinin bir portresini ortaya koymada anlık bir görüntüden öteye geçemez. Halbuki, ölçme-değerlendirme uygulamaları gerçek hayattaki durumlara benzer, kapsamlı ve bütünsel olmalıdır (McAlister, 2000). Geleneksel ölçme-değerlendirme, dar zamanda öğrencilerin bilgi düzeyindeki hedef ve davranışlarını ölçtüğü için diğer üst düzey hedef ve davranışlarını (uygulama, analiz, sentez vb.) ölçmede yetersiz kalmaktadır (Şaşmaz Ören, Ormancı ve Evrekli, 2011).

Geleneksel değerlendirme öğrenilenlerin tekrarına odaklanır ve genellikle öğrencileri sıralar, fakat öğrencilerin yeteneklerini ve bireysel performanslarını değerlendirmek için alternatif ölçme-değerlendirme yaklaşımlarına yönelmek gerekir (Watt, 2005). Alternatif ölçme-değerlendirme yaklaşımı, tek amacı öğrencilere not vermek olan geleneksel anlayışın aksine, not vermenin yanında ilerleme aşamaları ve eksikleri ile ilgili öğrencilere dönüt vererek öğrenmeyi destekleyen bir yaklaşımdır (Karamustafaoğlu, Çağlak ve Meşeci, 2012). Değerlendirme etkinliği gerçek hayatla ne ölçüde bağlantılı olursa o ölçüde geçerli olur. Bu nedenle alternatif ölçme ve değerlendirme araçları, örneğin performans, portfolyo, vb. gerçek hayatla iç içe olan araçlardır (McAlister, 2000). Alternatif ölçme-değerlendirme yaklaşımında; öz değerlendirme, akran değerlendirme, ortak değerlendirme, bireysel ürün dosyaları (portfolyo), mülakat, günlük, anket, proje, kavram haritaları ve drama gibi tekniklerin kullanılması önerilmektedir (Mintah, 2003; Van de Walle, 2007; Malatyalı ve Yılmaz, 2010).

Yapılandırmacı yaklaşıma göre her öğrenci bilgiye kendine özgü anlamlar yüklemektedir. Kişiye özgü bu anlamaların sadece yazılı yoklamalar ve çoktan seçmeli testlerle ölçülmesi mümkün değildir (Yazıcı ve Sözbilir, 2016). Dolayısıyla, ölçme-değerlendirme sürecinde alternatif ölçme-değerlendirme yöntemlerine yer veren yaklaşımların kullanılması çağdaş eğitim anlayışı için önemlidir (Yenice, Özden ve Alpak Tunç, 2017). Alternatif ölçme-değerlendirme yaklaşımında amaç uygun ölçme aracı kullanarak davranışı ölçmek ve öğrenme eksikleri konusunda öğretmene yol göstermektir (Kuran ve Kanatlı, 2009).

Ülkemizde ölçme-değerlendirme, öğretmen yeterlikleri arasında yer alan başlıklardan biridir. MEB'in 2017 yılında yayınladı̆̆ı öğretmenlik mesleği genel yeterliklerine göre, öğretmen, ölçme-değerlendirme boyunca süreç ve sonuç odaklı yaklaşım kullanmalı, ölçme araçlarını öğrencilerin gelişimsel özelliklerine uygun hazırlamalı ve ölçme-değerlendirme sonuçlarından elde edilen geri bildirimler ile eğitim öğretim ortamını yeniden düzenleyebilmelidir (MEB, 2017). Ülkemizde bu konuda yapılan çalışmalar farklı branşlardan öğretmenlerin ve öğretmen adaylarının alternatif ölçme-değerlendirme araçlarını kullanma konusunda yetersiz olduklarını ya da kendilerini yetersiz gördüklerini, bu nedenle de geleneksel ölçme-değerlendirme yöntemlerini kullanmaya devam ettiklerini göstermektedir. Şaşmaz Ören, Ormancı ve Evrekli (2011) fen ve teknoloji öğretmen adaylarıyla yürüttükleri bir çalışmada, adayların alternatif ölçme-değerlendirme araçlarını dersin sonunda kullandıklarını belirlemiş ve bu sonucu adayların kendi eğitimlerinin geleneksel ölçme-değerlendirme anlayışıla gerçekleşmesine dayandırmışlardır. Aynı çalışmada, bu durumun öğretmen adaylarının, alternatif ölçme-değerlendirmeyle ilgili yeterli bilgiye ulaştıklarında düşüncelerinin değişeceği ve mesleğe başladıklarında alternatif ölçme-değerlendirme araçlarını kullanmaya istekli olduklarını, bu araçların etkili ve kalıcı öğrenmeyi desteklediğinin farkında olduklarını belirtmişlerdir (Şaşmaz Ören, Ormancı ve Evrekli, 2011).

Sınıf öğretmenleriyle yapılan bir çalışmada ise öğretmenlerin alternatif ölçme-değerlendirme araçlarından performans değerlendirme, proje, drama ve kavram haritalarını kullandıkları; yapılandırılmış kılavuz (grid) ve dallanmış ağaç tekniklerinin en az bilinen teknik olduğu, bu durumun yapılandırmacı yaklaşımın öğretmenler arasında tam olarak benimsenmemiş olmasından kaynaklandığı tespit edilmiştir (Karamustafaoğlu, Çağlak ve Meşeci, 2012). Matematik öğretimiyle ilgili sınıf öğretmenleriyle yapılan başka bir çalışmada alternatif ölçme-değerlendirmeyle ilgili öğretmenlerin yaşadıkları problemler arasında internetin yanlış kullanımından dolayı öğrencilerin ödevlerini hazır olarak indirmeleri, ödevlerini velilerine yaptırmaları, öğrencilerden grup 
çalışması yapmaları istendiğinde okul dışında görüşememeleri, öğrencilerin öz-değerlendirme formlarını tarafsız bir şekilde doldurmamaları gösterilmiştir (Bal ve Doğanay, 2010).

Fizik, kimya ve matematik öğretmenleriyle yapılan başka bir araştırmada ise, öğretmenlerin en çok kullandıkları ölçmedeğerlendirme araçlarının yazılı sınav, soru-cevap, problem çözme ve ödev olduğu; alternatif ölçme-değerlendirme tekniklerinden deney raporları, günlük, portfolyo ve kavram haritalarının ise pek bilinmediği, dolayısıyla öğretmenlerin yetersiz bilgiden dolayı alternatif değerlendirme yaklaşımını benimsemedikleri belirtilmiştir (Nazlıçiçek ve Akarsu, 2008). Aynı çalışmada öğretmenlerin, derse katılımın öğrencilerin başarısını ve performansını göstermede doğru sonuçlar verdiğini düşündükleri söylenmiş, bunun dışında öğretmenlerin öğrencilerin gayretine, problem çözmelerine ve gelişimlerine önem verdikleri belirtilmiştir.

Büyüktokatlı ve Bayraktar (2014) yaptıkları çalışmada öğretmenlerin büyük çoğunluğunun (\%59) alternatif ölçme ve değerlendirme yöntemlerini uygulamada zorluklar çektiğini belirtmişlerdir. Öğretmenler alternatif ölçme-değerlendirme yöntemlerini kullanmama nedenleri olarak kalabalık sınıfları, zaman kısıtlamalarını, ebeveynlerin tutumlarını ve alternatif ölçmedeğerlendirme yöntemleri hakkında bilgi eksikliklerini gerekçe göstermişlerdir (Büyüktokatlı ve Bayraktar, 2014). Göktaş ve Arıbaş (2014)'ın dokuz matematik öğretmeni ile yaptıkları çalışmada öğretmenlerin yazılı, performans görevi, proje, çoktan seçmeli test ve öz değerlendirme formu gibi ölçme araçlarını daha çok kullandıkları sonucuna ulaşmışlardır. Çalışmanın sonuçlarına göre öğretmenlerin geleneksel ölçme-değerlendirme yöntemlerinde kısmen yeterli olduklarını, alternatif ölçme-değerlendirme yöntemlerinde ise hizmet içi eğitime ihtiyaç duydukları sonucuna ulaşmışlardır.

Bu çalışmada ise, nitel veri zenginliği kullanılarak, ortaokul matematik öğretmenlerinin ölçme-değerlendirmeyi nasıl yaptıkları ve ölçme ve değerlendirmeye bakış açılarının neler olduğu yapılandırmacı yaklaşım çerçevesinde ele alınarak araştırılmış ve öğretmenlerin alternatif ölçme ve değerlendirme yöntemlerine olan farkındalıklarının ne düzeyde olduğu incelenmiştir.

İlköğretim Kurumları Yönetmeliği ve yapılandırmacı yaklaşım çerçevesinde değiştirilen ortaokul matematik programı öğretmenlerin alternatif ölçme-değerlendirme yöntemlerini kullanmasını önermektedir. Bu bakımdan çalışmanın, mevcut sistemde ortaokul matematik öğretmenlerinin ölçme ve değerlendirmeyi nasıl ve neden yaptıklarının belirlenmesi açısından önemli olduğu düşünülmektedir. Ayrıca bu çalışma, yenilenecek öğretim programlarında öğretmenlere ölçme-değerlendirme konusunda nasıl yön verileceğin belirlenmesi açısından da önemli olabilir.

\section{YÖNTEM}

Ortaokul matematik öğretmenlerinin ölçme-değerlendirmeyi neden ve nasıl yaptıklarını inceleyen bu çalışma bir durum çalışmasıdır. Çalışma, amacına uygun olarak nitel araştırma desenlerinden çoklu durum çalışması deseni ile tasarlanmıştır. Çoklu durum çalışmasında araştırmacının tekrarlama mantığını kullanması, yani araştırmacının her durum için aynı prosedürleri takip etmesi önerilmektedir (Yin, 2017, s. 8).

\section{Katılımcılar}

Katılımcılar, Mersin ili merkez ilçelerinde görev yapmakta olan, beş farklı ortaokuldan seçilen beş ortaokul matematik öğretmenidir. Her matematik öğretmeni bu durum çalışmasının bir 'analiz birimi'dir (Yin, 2017, s. 34). Katılımcıların belirlenmesi amaçlı örnekleme ile gerçekleşmiştir. Ayrıca katılımcıların belirlenmesinde, amaçlı örneklem kapsamında kullanılan, birçok temayı içeren ana temaları bulup tanımlamayı amaçlayan 'maksimum çeşitlilik örneklemi' oluşturulmaya çalışımıştır (Patton, 2014, s. 235). Bu bakımdan, öğretmen seçimlerinde mesleki tecrübe, cinsiyet ve çalıştığı merkez ilçe açısından farklılık gösterebilecek ortaokul matematik öğretmenlerinden oluşan bir katılımcı grubu oluşturulmaya çalışılmıştır. Aşağıda verilen Tablo 1'de katılımcılara ait demografik bilgiler görülmektedir.

Tablo 1. Katılımcılara ait demografik bilgiler

\begin{tabular}{lccc}
\hline Öğretmenler* & Tecrübesi & Mezun olduğu fakülte / bölüm & Cinsiyet \\
\hline Aylin Öğretmen & 18 yıl & Fen Fakültesi - Matematik & Kadın \\
Banu Öğretmen & $1 \mathrm{yıl}$ & Eğitim Fakültesi - Illköğretim Matematik Öğretmenliği & Kadın \\
Cem Öğretmen & 11 yıl & Eğitim Fakültesi - Fen Bilgisi Öğretmenliği & Erkek \\
Devrim Öğretmen & $18 \mathrm{yıl}$ & Eğitim Fakültesi - Sınıf Öğretmenliği & Erkek \\
Engin Öğretmen & $20 \mathrm{yıl}$ & Fen Fakültesi - Matematik & Erkek \\
\hline
\end{tabular}

*Öğretmenlerin isimleri araştırma ekibi tarafından verilen takma isimlerdir.

Aylin Öğretmen, formasyon eğitimi alarak öğretmen olmuş, şehir merkezinde bir ortaokulda çalışmaktadır. Okulda diğer öğretmenlerden daha fazla deneyime sahip olması sebebiyle zümre kararlarının alınmasında yol gösterici olduğu düşünülmektedir. Banu Öğretmen, aynı zamanda bir doktora öğrencisi olarak şehir merkezinde bir okulda çalışmaktadır. Cem Öğretmen, 4 yıl fen ve teknoloji dersi öğretmenliği yaptıktan sonra alan değiştirerek ortaokul matematik öğretmenliğine geçmiştir. Görevine devam ettiği okulda matematik öğretmenleri zümre başkanlığı görevini de yürütmektedir. Devrim Öğretmen ise, 13 yıl sınıf öğretmeni olarak görev yaptıktan sonra alan değişikliğiyle ortaokul matematik öğretmenliğine geçmiştir. Engin Öğretmen, şehir merkezinde bulunan, genel olarak popüler kabul edilen bir devlet okulunda çalışmaktadır ve öğrencilerinin çoğunun etütlerden ve çeşitli kurslardan destek aldığını ve sosyo-ekonomik seviyelerinin iyi düzeyde olduğunu belirtmiştir. Bu farklı tecrübe ve çalışma ortamları dikkate alındığında, katılımcıların maksimum çeşitlilik gösterdikleri söylenebilir. 


\section{Veri Toplama Araçları}

$\mathrm{Bu}$ çalışmada kullanılan temel veri toplama araçları görüşme, gözlem ve dokümanlardır. Birincil veri toplama aracı görüşmelerdir. Bazı katılımcılarla gerek görüldüğünde birden fazla görüşme gerçekleştirilmiştir ve izinleri doğrultusunda ses kaydı alınmıştır. Görüşmede öğretmenlere yöneltilen sorulardan değerlendirmeyi nasıl yaptıkları ve niçin yaptıkları hakkında fikirler elde edilmiştir. Bu sorulardan birkaçı 'öğrencilerin bilgilerini ve performanslarını değerlendirmek için hangi ölçme-değerlendirme yöntemlerini kullanmayı tercih ediyorsunuz?', 'ölçme sonucunda elde ettiğiniz verileri hangi amaçlarla kullanıyorsunuz?’ ve 'ölçmedeğerlendirme konusunda kendinizi yeterli görüyor musunuz?' şeklindedir.

İkincil veri toplama aracı olarak, gözlem, her katılımcının uygun gördüğü ders saatinde bir araştırmacı tarafından gerçekleştirilmiştir. Araştırma ekibi, gözlem yapmadan önce hazırladıkları gözlem formları ile öğretmenlerin en az bir ders saatini gözlemlemişlerdir. Bazı katılımcılar için gerekli görüldüğünde gözlem sayısı artırılmıştır. Katılımcı gözlem çalışmalarında yer alan kişilerle yakın, uzun süreli iletişim gerektiği için (Fetterman, 2010, akt. Creswell, 2018) araştırmacılar, katılımcıların birden fazla dersini gözlemlemiş ve dersler dışında da okulda birlikte zaman geçirmişlerdir. Ders içi gözlem yapılmadan önce öğretmenden ders konusu hakkında bilgi alınarak ve ders öncesi öğrenciler ile iletişim kurularak gözlem yapılacak ortam objektif hale getirilmiştir.

Son veri toplama aracı olarak, her katılımcıdan kullandıkları değerlendirme yöntemleri için birer örnek doküman istenmiştir, bu dokümanların neler olacağını ve bir örneğini verme konusunda katılımcılar serbest bırakılmıştır. Öğretmenlerin kullandıkları ölçme ve değerlendirme araçları ve yöntemleri ile ilgili dokümanların, araştırmacılar tarafından birer kopyası alınmıştır.

\section{Veri Analizi}

Araştırmada, nitel veri analizi yöntemlerinden içerik analizi tekniği benimsenmiştir (Miles ve Huberman, 1994). Veri toplama araçları (görüşme protokolü ve gözlem formu) hazırlandıktan sonra, yukarıda açıklanmış teorik çerçeve kapsamında olası tema ve kodlar araştırma ekibi tarafından belirlenmiştir. Veri toplama süreci tamamlandıktan sonra elde edilen veri, tema ve kodlara göre kodlanmış ve düzenlenmiştir. Bu kodlama işlemi her katılımcı ile görüşme yapan araştırmacı tarafından yürütülmüştür. Bu süreç tamamlandıktan sonra araştırma ekibi bir araya gelerek yaptıkları kodlamaların tutarlılı̆̆ını incelemişlerdir. Bu çalışmada kodlayıcılar arasındaki uyum oldukça yüksek çıkmıştır.

Nitel çalışmaların güvenirliği verilerin kodlanmasında farklı kodlayıcıların kodlamaları arasındaki uyum anlamına gelmektedir (Creswell, 2018, s. 253). Bulguların yorumlanmasında öğretmenlerle yapılan görüşmelerden önemli alıntılara yer verilerek, bulguların desteklenmesi yoluna gidilmiştir. Bunlara ek olarak, görüşmenin çözümlemesi yapıldıktan sonra, katılımcılara gösterilmiş ve doğru aktarılıp aktarılmadığı konusunda görüşleri alınmıştır. Çoğu nitel çalışmada toplanan verilerin, analiz, yorum ve sonuçların tekrar katılımcıya gönderilmesi ortaya konan açıklamaların doğruluğu ve inandırıcılığı açısından gereklidir (Creswell, 2018, s. 252). Bu da çalışmanın güvenilir olduğunu gösterir.

\section{BULGULAR}

Bu bölümde, ilk olarak bulgular her durum için ayrı ele alınacak ve sonrasında, durumların karşılaştırmalı analizi genel bulgular şeklinde verilecektir.

\section{Durum 1: Aylin Öğretmen}

Aylin Öğretmen, ölçme aracı olarak yazılıları, sözlüleri ve proje ödevlerini kullandığını belirtmiştir. Bu ölçme araçlarını değerlendirmede kullanmaktadır. Aylin Öğretmen, proje ödevini kullanma sebebini şöyle açıklamaktadır:

“Projede kâğıt ödevi vermiyorum. Genellikle günlük hayatta karşılaşacakları bir şeyler veriyorum. Öğrenciler bir ürün sunmuş oluyorlar. Bunların öğrencilerin derse bağlılığını artırdığını düşünüyorum. Bu ürünlerin sunumunu yapıyorlar, sınıf ortamında değerlendirip öğrencilere geri veriyorum ödevlerini. Öğrencilerin bir ürün ortaya koymuş olmalarını önemsiyorum."

Aylin Öğretmen, ürün oluşturmaya yönelik bir proje ödevi taslağını bizimle paylaşmıştır. Dersinde yapılan gözlemde ödevleri kontrol edip bir listesini tuttuğu görülmüştür. Öğretmen bu dersinde ödevleri kontrol edip bu ödevde yapılamayan ya da anlaşılamayan yerleri öğrencilere anlatmıştır. Ödev kontrol listesini dönem sonunda öğrencilerin ders ve etkinliklere katılım notlarını vermek ve değerlendirmede kullandığı bu aracı velileri bilgilendirmek için kullandığını belirtmiştir. İsteğimiz üzerine katılımcı bu uygulamayı yaptığı bir dokümanı bizimle paylaşmıştır (aşağıda Şekil 1'de görülebilir, "görülmüştür" şeklinde velinin imzası silinmiştir). Bu öğrenci kağıdında not değeri olmayıp sadece öğrenme eksiklikleri belirlenmiştir. Ayrıca, öğrencinin eksik olduğu konuları belirtip, kâğıdı veliye gönderdiği gözlenmiştir. 


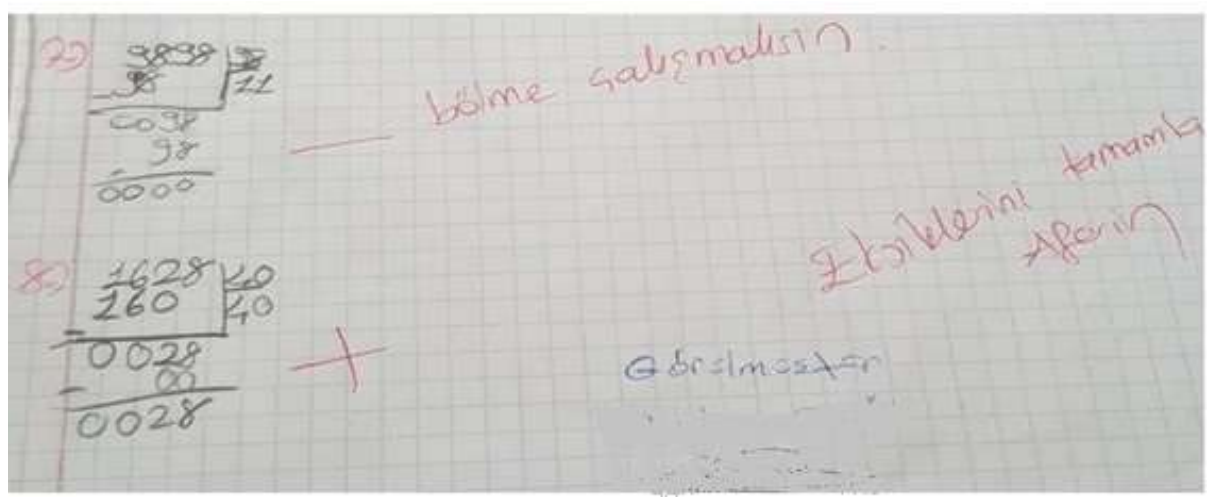

\section{Şekil 1. Aylin Öğretmen'in kullandığı ölçme aracından bir örnek}

Aylin Öğretmen ölçme-değerlendirme sürecinin çeşitlendirilmesi gerektiğini belirtmiştir. Sadece yazılı sınavlara bakılmaması gerektiğini, yazılı notlarının sadece anlık sonuçlar olduğunu, öğretmenler olarak bu konuda kendilerini geliştirmeleri gerektiğini söylemiştir. Öğrencilerin anlık yapılan yazılı sınavlardan kötü not alabildiklerini, bu notun öğrencinin matematiğe tutumunu olumsuz etkilediğini; ayrıca öğrencilerin proje ödevi yapma sürecini daha çok sevdiklerini belirtmiştir.

Aylin Öğretmen İlköğretim Kurumları Yönetmeliği’ne göre yazılı, sözlü ve proje ödevlerini yapmanın zorunlu olduğunu ve ölçme-değerlendirme ile ilgili yapılan uygulamaların evraklarının hazırlanmasının ayrı bir yük getirdiğini söylemiştir. Ölçme araçlarının öğrenciler için açık ve anlaşılır olması gerektiğini ve kazanımlara uygun olması gerektiğini ifade etmiştir. Ölçme araçları hazırlanırken fikir alışverişi yapmak amacıyla zümre öğretmenleri olarak iyi araçlar hazırlanabileceğini belirtmiştir.

Aylin Öğretmen öğrencilerin dönem sonu notunu oluştururken yazılıları, projeleri ve ödevleri kullandığını açıklamıştır. Bunun yanında öğrencinin derse katkısının ve öğrenci hakkındaki izleniminin de nihai nota etki ettiğini, dersinden öğrencilerin kötü not almalarını istemediğini ve kötü notun zamanla öğrencilerin derse olan ilgilerini azalttığını belirtmiştir. Bu nedenle, not verirken değerlendirmeye öğrenciye ait diğer faktörleri (derse katılım, ödevler, derse karşı tutum vb.) dâhil ettiğini açıklamıştır.

\section{Durum 2: Banu Öğretmen}

Görüşmede, Banu Öğretmen yaptığı ölçme ve değerlendirmenin kısa soru-cevaplar, yazılı, sözlü ve öğrencinin yaptığı özdeğerlendirme ve portfolyodan oluştuğunu aktarmıştır. Genel olarak, ders içi performansı yazılıdan daha çok önemsediğini dile getirmiştir. Burada onun için önemli olan, öğrencilerin iyi puan almasından çok konu hakkında tüm bildiklerini ne düzeyde aktarabiliyor oldukları ve kendi durumlarının farkında olmalarını istemesi olarak özetlenebilir. Banu Öğretmen ile yapılan görüşmeden bir alıntı aşağıda verilmiştir:

“Öğrencinin dersteki performansı önemli. Ben yeri geliyor sözlü, quiz [mini sınav] yapıyorum. [...] En başta öğrencinin kendinin farkında olmasını sağlamak istiyorum. 'Yani öğreniyor muyum diğerlerine göre nasılım? Diğerlerine göre ekstra bir çaba sarf etmek gerekiyor mu?' diye kendini sorgulasın istiyorum."

Burada bahsedilen mini sınav, öğrencilere ünite sonlarında yaptığı bir kazanım değerlendirme ölçeğidir. Öğretmen, yaptığı değerlendirme için öğrencilerin aldıkları notlardan ziyade belirlenen konuya ait kaç tane kazanıma hâkim olup olmadıklarını fark ederek kendisinin daha kontrollü ders işlediğini, ders planlamasını bu sayede başarılı gerçekleştirdiğini aktarmıştır. Banu Öğretmen, ayrıca, aktarılan konunun aşamalarına göre sadece dersi değil, değerlendirmelerini de planlamaktadır. Öğrenilen konuya ayrılan zamanı, giriş, gelişme (sürecin tamamı) ve sonuç olarak üç parçaya böldüğünü ve her bölümde farklı soru tipleri ile değerlendirme yöntemlerini kullandığını belirtmiştir.

Öğrencilerin sınıfta aktif rol alması, davranışları ve ders araç-gereci bulundurma sorumluluğu gibi unsurların Banu Öğretmen için önemli olduğu ve öğrencilere verdiği not için bunları da değerlendirdiğini yapılan görüşmede şöyle belirtmiştir:

"Bende, girdiğim her sınıf için dosyamda 3 tane liste var. Biri araç gereç listesi, muhakkak kontrolü yaparım; ikincisi ödev kontrol listesi. Muhakkak sınıfta bir kişiyi seçer, ben gelmeden önce teneffüslerde kontrol etmelerini sağlarım. Bir üçüncüsü de derse katılım listemdir. Muhakkak öğrencide bir çaba gördügüumde ya da dersimi sabote eden varsa listemde not alırım."

Burada belirtilen üç dosya incelendiğinde, Banu Öğretmen'in öğrencilerin isimlerinin yanına artı veya eksi koyduğu görülmüştür. Bu değerlendirmenin dönem sonu nihai notu verirken yardımcı olduğunu açıkladı. Öğrencilerinin süreç içerisindeki değerlendirmelerini +/- olarak yaptığında sadece kendisinin değil aynı zamanda okul yöneticisi ve velilerin de her öğrencinin değişim ivmesini görebildiğine değindi.

Yapılan görüşmede son olarak Banu Öğretmen, okul yöneticisi ve zümre öğretmenlerinin değerlendirme zamanı, içeriği ve ölçekler hakkında birlikte karar vermelerini ve aynı ölçme aracını kullanmalarını mantıklı ve etkili bulmadığını söyledi. Bu şekilde yapılmasının kendisini kısıtladığını ve elinden gelenin en iyisinden ziyade öğrencilere didaktik ve geleneksel bir bakış açısıyla yaklaşmak zorunda kaldığını açıkladı. Girdiği sınıfların yapısı farklı olduğu için aynı sınavın yapılmasını uygun görmemektedir. Her öğretmenin sınıfa özgü ölçme ve değerlendirmeler yapması gerektiğini söyledi. Bu sayede öğrencileri için daha verimli olabileceğini ve onların öğrenmesinde daha büyük rol oynayabileceğini aktardı. 


\section{Durum 3: Cem Öğretmen}

Cem Öğretmen, ölçme ve değerlendirmede yazılı, mini sınav, performans, proje ödevi gibi araçları kullandığını ifade etmiştir. Ayrıca yazılı sınavlarında ağırlıklı olarak çoktan seçmeli olmak üzere, boşluk doldurma, doğru-yanlış ve açık uçlu sorulara yer verdiğini belirtmiştir. Sınıfların başarı seviyelerine göre test şeklinde deneme sınavları yapmaya çalıştığını ifade etmiştir. Cem Öğretmen'in ölçme-değerlendirmeyi neden yaptığına ilişkin cevabı şöyledir:

“Öncelikle çocukların eksikliklerini [tespit ederek], dönüt vermek için kullanıyorum. Velilerin çocukların durumundan haberdar olması için kullanıyorum, yani başarı düzeyini ölçmek için kullanmaya çalışıyorum, çalışmalarımız sınava yönelik olduğu için öncelikle [kendi] eksiklerimi tamamlamak için kullanıyorum."

Ölçme-değerlendirme konusunda kendini, üniversite eğitimi sırasında öğretilenler çerçevesinde yeterli bulduğunu ancak bir seminer, kurs, vb. olursa katılmak istediğini belirtmiştir. Buradan, Cem Öğretmen'in kendini geliştirmek için bir çaba içinde olduğu yorumu yapılabilir.

Öğrencilerin nihai notlarını verirken daha yüksek puan almalarını sağlayacak şekilde değerlendirme yapmaya çalıştığını, bunu eğitim sistemimizin sınav odaklı olması nedeniyle öğrencilere daha adil yaklaşmak maksadıyla yaptığını aşağıdaki gibi belirtmiştir:

“[B]en burada yapılan sınavlarda sınavın geçerlik ve güvenirliği konusunda biraz sıkıntı olduğunu düşünüyorum, neden diye sorarsanız... Bizim eğitim sistemimiz maalesef sınava yönelik olduğu için bir sınavda okul başarısı, okul puanını [...] etkilediği için hani çocukların bu konuda mağdur olmamaları için ya soruları kolay sormaya çalışıyoruz ya da onlara belli bir puan vererek onları desteklemeye çalışıyoruz. Başka özel okullarda çocukların sözlüsüne yazılısına yüksek puanlar verildiğini işitiyoruz; tabi yanlış mı bilemeyiz ama. Biz de [kendi öğrencilerimizin] mağdur olmaması, negatif ayrımcılık olmasın diye desteklemeye, soruları kolay sormaya çalışıyoruz. Bu konu da eğitimin kanayan bir yarası, bu konuda yapabileceğimiz bir şey yok ama bir çözüm bulunsa bence güzel olur."

Buradan, Cem Öğretmen'in ölçme-değerlendirmeyi aslında sistemin bir gereği olduğu için yaptığını ve bu durumdan rahatsızlık duyduğunu söyleyebiliriz. Cem Öğretmen'in gerçekte öğrenciyi gözlemlediği, ders içi ve ders dışı çalışmalarla bir kanaati oluştuğu ama oluşan kanaati doğrultusunda çok etkili bir değerlendirme yapamadığı, yüksek not verme ya da düşük not vermeme kaygısı yaşadığı söylenebilir.

İncelenen dokümanlarda, Cem Öğretmen'in ödevler için kontrol listesi oluşturduğu ve ödev kontrollerini öğrenciye yaptırdığı, dönem sonlarında kontrol listelerini öğrencilerden alarak değerlendirmeye dahil ettiği belirlenmiştir. Ayrıca her yazılı sınav için dereceli puanlama anahtarı hazırlamaktadır. Yazılı sınavlarda öğrencilerin yüksek not almaları için soruları, önceden ödevlendirdiği ders kitabından seçtiği ve yazılı sınavlarda öğrencilerin yüksek not almaları için en az bir tane joker soru sorduğu da görülmüştür.

\section{Durum 4: Devrim Öğretmen}

Devrim Öğretmen yapılan görüşmede ölçme aracı olarak yazılı, çoktan seçmeli test, soru-cevap, sınıf içi gözlem ve ödevleri kullandığını belirtmiştir. Derste en çok soru-cevap tekniğini kullandığını söylemiş ve "çocukların bilgilerini ölçecek sorular sorarak o konuya nasıl başlanacağına öğretmen olarak yön veriyorum. Gidişatım böyle olmalı [...]" şeklindeki ifadesiyle ders başlangıcında öğrencilerin ön bilgilerini belirlemeyi amaçladığı görülmüştür. Ders süresince ve ders bitiminde yaptığı ölçme-değerlendirmede ise süreci değerlendirdiğini, eksiklikleri saptayıp tamamlama yoluna gittiğini belirtmiştir. Yaptığımız gözlemde söyledikleriyle tutarlı şekilde davrandığı görülmüştür.

İşlenen konuların evde tekrar edilmesi ve pekiştirilmesi için ödevler verdiğini, ödev kontrolünün kendisinin görevlendirdiği öğrenciler tarafından dersten önce yapılarak kontrol listesi oluşturulduğunu ifade etmiştir. İncelenen dokümanlarda kontrol listelerinin artı ve eksi verilerek oluşturulduğu görülmüştür. Bu ödevlerle ilgili eksiklikleri olan öğrencilerin velileriyle irtibata geçerek birebir görüştüğünü belirtmiştir. Bu kontrol listeleri veli görüşmeleri için öğretmene bir kaynak sağlamaktadır. Buradan, değerlendirmeyi velileri bilgilendirmek için de kullandığı söylenebilir.

Devrim Öğretmen, yazılıları birden fazla kaynaktan yararlanarak kazanımlara uygun şekilde hazırladığını, puanlama hakkında öğrencilere yönerge verdiğini, dereceli puanlama yaptığını söylemiştir. Bu sayede, yazılıları değerlendirirken öğrencilerin de dolaylı olarak katkı sağlayarak olası dikkatsizliklerinin önüne geçtiğini belirtmiştir. Devrim Öğretmen böyle bir anahtar kullanarak öğrencilerin verdikleri cevapların doğruluğu konusunda objektif değerlendirme yaptığını düşünmektedir. Ek olarak, eğitim-öğretim sürecinde değerlendirmeyi öğrenciyi sınıflama ya da sıralama amacıyla kullanmadığı söylenebilir.

Ders içi etkinlik notu verirken öğrenciyi sadece ders başarısıyla değil bütün yönleriyle değerlendirdiğini “Ders içi izlenimler, [...] çocuğun derse katılımı, ders içindeki davranışı, sınıf içi kurallara uyma, bunların bütünü şeklinde düşündüğümüzde çocukların notları zaten öğretmenin kafasında oluşuyor." sözleriyle ifade etmiştir. Bu ifadeden yararlanarak sonuç odaklı değil süreç odaklı bir değerlendirme yaptığı söylenebilir.

Devrim Öğretmen, ölçme-değerlendirme konusunda üniversite eğitimi dışında herhangi bir eğitim almadığını ve eksiklikleri olabileceğini ifade etmiştir. Ölçme ve değerlendirmeye sistemin getirdiği bir zorunluluk gözüyle bakmadığını, aksine, öğrenme sürecinde oluşabilecek eksikliklerin belirlenmesinde önemli rolü olduğunu vurgulamıştır. Dolayısıyla, ölçme-değerlendirme ile öğrenme sürecinin eksiklerini belirlemeyi hedefliyor diyebiliriz. Devrim Öğretmen uyguladığı ölçme-değerlendirme sürecini kendi öğretmenlik becerilerine yön vermek için gerekli gördüğünü ifade etmiştir. Buradan, mevcut öğretim programının önerdiği ölçme ve değerlendirme çalışmalarını yeterli ve gerekli gördüğü anlaşıımaktadır. 


\section{Durum 5: Engin Öğretmen}

Engin Öğretmen'in ölçme-değerlendirme araçlarını yazılı, öğrencinin derse katılımı, öğrencinin derse ilgisi ve proje oluşturmaktadır. Yazılı hazırlarken test çoğunlukta olmak üzere, daha yararlı olduğuna inandığı için klasik sorulara da yer verdiğini, boşluk doldurma, doğru-yanlış, vb. soru türlerini de dâhil ettiğini belirtmiştir.

Ayrıca, özellikle sınav sisteminde okul puanının etkili olması nedeniyle "biraz da not kaygısından dolayı yüksek alabilecekleri sorular soruyorum." şeklindeki ifadesiyle liselere geçiş sınav sisteminin öğretmenler üzerinde de bir kaygı yarattığını ve ölçmedeğerlendirme sürecini etkilediğini söyleyebiliriz.

Son dönemlerde öğretmenler arasında internet aracılı̆̆ıyla belge paylaşmanın kolaylaştığını, bu yüzden pek çok öğretmenin başkalarının hazırladığı yazılıları indirip uyguladığını ve bunu doğru bulmadığını, dolayısıyla soruları kendisinin hazırladı̆̆ını ifade etmiştir. Öğrencilerle dersteki etkileşimi doğrultusunda sınavda kolay sorular olduğu kadar zor sorulara da yer verdiğini belirtmiştir. Ders süresince ölçme-değerlendirmeye ne sıklıkla yer verdiği sorulduğunda, konu anlatımından sonra kendisinin örnekler çözdüğünü, sonrasında öğrencilere de tahtada mutlaka soru çözdürdüğünü ifade etmiştir. Bununla ilgili olarak öğretmenin bunu önemli bulduğunu ve tahtada soru çözmenin öğrenmede kalıcılık sağladığını düşündüğünü belirtmiştir.

Derse katılım dışında Engin Öğretmen ödev kontrolünü de değerlendirme aracı olarak kullanmaktadır. Öğrencilere ödev kontrol listesi hazırlatıp dönem sonunda vereceği nihai notta onu da göz önünde bulundurduğunu ifade etmiştir. Hangi aşamalarda ölçmedeğerlendirme tekniklerini kullandığı sorulduğunda ise, konu başlangıcında öğrencilerin ön bilgilerini belirlemek için, konu bitiminde ise ne kadar öğrendiklerini tespit etmek için mutlaka 20 soruluk deneme sınavı yaptığını ve mobil uygulama kullanarak madde analizinden faydalandığını belirtmiştir. Buradan elde ettiği sonuca göre "mesela, yapılma oranı yüzde kırk ise demek ki ben bunu anlatamamışım. Onun üzerine bir daha dönüp onunla ilgili soru çözüyorum ki oran yükselsin." şeklinde bir yol izleyebildiğini belirtmiştir. Dolayısıyla, değerlendirmeyi sadece öğrenciyi değerlendirmek için değil kendini değerlendirmek için de yaptığını söyleyebiliriz.

Engin Öğretmen'in öğrencinin derse karşı tutumuna ve gayretine önem verdiğini açıklayan bir başka örnek de performans notlarının dağılımında uyguladığı planda ortaya çıkmaktadır. Engin Öğretmen, bunu şöyle açıklamıştır:
“Mesela benim kriterim şu; üç tane performans notu vereceksem birisi yazılı notunun yüzde 20 üstü -altını genelde vermiyoruz-; ikincisi sınıftaki durumu, davranışı, tutumu, katılımı; üçüncüsü de tamamen o çocuğun ne kadar uğraştığına, [...] gayretine göre [veriyorum]. Mesela çocuk çok gayretli ama yazılıdan düşük not almış. [...], onun gidip de notunu düşürmenin bir anlamı yok. Bu yaş grubunda çok mantıklı olmuyor."

Engin Öğretmen, küçük yaş grubundaki öğrencilerin hevesini kırmamak ve onları motive etmek gerektiğini düşünerek öğrenciyi mutsuz edecek notlar verilmesini doğru bulmadığını aşağıdaki gibi ifade etmiştir:

“Lisede ne yaparsan yap ama, dedim ya [...] çocuk 70'lik ama 90'ı veriyorsun diye. Benim elim gidiyor yani, 90'ı rahat rahat veriyorum. Ama ona da hissettiriyorum onun hakkı olmadığını [...]. Onun haricinde başka da yapacak bir şey yok. Bir de ne diyeyim ki yani not sistemi ve bu sınav sistemi oldukça da yapacağın çok fazla bir şey yok."

Öğretmenin ölçme-değerlendirme konusunda seçeneklerini kısıtlayan bir sınav sistemi olduğunu düşünmesi öne çıkan bulgulardan biridir. Özetle, Engin Öğretmen'in yeniliklere açık bir öğretmen olmasına rağmen alternatif ölçme-değerlendirme tekniklerini kullanamamasına sebep olarak, sınıfların kalabalık olmasını, sınav sistemini ve öğrencilerin küçük yaş grubunda olmalarını göstermiştir. Son olarak, ölçme-değerlendirme konusunda kendini hiçbir zaman yeterli görmediğini, daha önce bir kursa katıldığını ama yeterli olduğunu düşünmediğini de ifade etmiştir.

\section{Durumların Karşılıklı Analizi}

Bu bölümde yukarıda verilen durumlar karşılıklı analiz edildiğinde bulgular üç başlık altında toplanabilir: Birincisi; öğretmenlerin değerlendirme yapmaktaki amaçlarıdır. Bulgular incelendiğinde tüm öğretmenlerin değerlendirme yapmalarının temel amaçları arasında öğrencilerin öğrenme eksiklerini belirlemek, öğretim sürecinin etkililiği hakkında bilgi edinmek ve velileri öğrenci hakkında bilgilendirmek olduğu görülmektedir. Hatta, bazı öğretmenlerin değerlendirmelerine hassas yaklaştıkları ve bu nedenle de dereceli puanlama anahtarı kullandıkları fark edilmiştir. Bunun yanında bazı öğretmenlerin (Devrim ve Engin Öğretmen) öğrencilerin ön öğrenmelerini belirleyip derse nasıl başlayacaklarına karar vermek için kullandıkları bulgusuna da ulaşılmıştır. Aylin Öğretmen'in değerlendirme yapma amaçları arasında matematik ve günlük hayatı ilişkilendirmek de olduğu görülmüştür.

İkincisi ise çalışmamıza dâhil olan öğretmenlerin kendilerini ölçme-değerlendirme etkinliklerini yapma zorunluluğunda hissetmeleridir. Araştırmanın bulgularına göre öğretmenlerin daha çok sözlü, yazılı sınav ve proje ödevi gibi geleneksel ölçmedeğerlendirme yöntemlerini kullandıkları görülmüştür. Öğretmenler bu yöntemleri mevcut sınav sistemi, yönetmelikte belirtilen yönergeler ve zümre öğretmenler kurulunda alınan kararlar sebebiyle zorunlu olarak kullandıklarını belirtmişlerdir. Bir katılımcı, yazılı sınavların anlık sonuçlar verdiği için yeterli olmadığını, bunun için alternatif ölçme-değerlendirme yöntemleri konusunda öğretmenlerin kendini geliştirerek süreci değerlendirmede kullanmaları gerektiğini belirtmiştir. Katılımcıların çoğu (Aylin, Banu, Devrim ve Engin Öğretmen) sınıf içi gözlem, ders içi performans ve ödevlerin yaptıkları değerlendirmede etkili olduğunu, diğer öğretmen ise bu tür gözlemlerini not kaygısı sebebiyle değerlendirmede kullanmakta çekimser kaldığını ifade etmiştir. 
Son olarak, katılımcıların tüm değerlendirme etkinlikleri sonunda öğrenciye verilecek nihai notu belirleme biçimleridir. Tüm öğretmenlerin nihai notu belirlerken yalnızca yazılılar ve projelerden değil, ders ve etkinliklere katılım puanlarından da yararlandıkları görülmüştür. Bazı öğretmenlerin (Aylin, Cem ve Engin Öğretmen) öğrencilerine nihai not verirken düşük not vermek istemedikleri, yüksek not verme eğiliminde oldukları ve ders ve etkinliklere katılım puanları ile öğrenci notlarını yükselttikleri bulgusuna ulaşılmıştır. Bu öğretmenler yüksek not verme eğiliminin nedenini eğitim sisteminin sınav odaklı olmasından ötürü notların önemli olmasına ve bazı okullarda notların bilinçli olarak yükseltilmesine bağlamışlardır. Bazılarının (Banu ve Devrim Öğretmen) ise, nihai notu oluştururken not yükseltme kaygısı taşımak yerine ölçme-değerlendirme sürecine ait bütün faaliyetleri (ödev listesi, davranışa yönelik +, - listesi, vb.) nihai notun oluşturulmasında kullandıkları gözlenmiştir. Banu, Devrim ve Engin Öğretmen'in nihai notu belirlemede öğrencinin ders içindeki davranışlarını, sorumlu davranışlarını ve derse karşı tutumlarını da kullandıkları sonucuna ulaşılmıştır.

\section{TARTIŞMA VE SONUÇ}

Devlet okullarında çalışmakta olan ortaokul matematik öğretmenlerinin ölçme-değerlendirmeye ilişkin bakış açılarını ve ölçmedeğerlendirme sürecini neden ve nasıl yönettiklerini incelediğimiz bu çalışmada, öğretmenlerin alternatif ölçme-değerlendirme yöntemlerine karşı pozitif bir yaklaşım sergiledikleri görülmüştür. Buna karşılık yapılan görüşmeler sonucunda öğretmenlerin sınıflarında geleneksel ölçme-değerlendirme uygulamalarını daha çok kullandıkları sonucuna ulaşılmıştır. Bu bulgu, Gelbal ve Kelecioğlu (2007)'nun araştırmasında yer alan “[ö]ğretmenlerin öğrencilerini tanımada ve başarı düzeylerini belirlemede daha çok geleneksel yöntemleri tercih ettikleri anlaşılmaktadır." sonucu ile birebir örtüşmektedir.

Araştırmada Aylin, Cem, Devrim ve Engin Öğretmen'in sözlü, yazılı sınav ve proje ödevi gibi geleneksel ölçme-değerlendirme yöntemlerini kullandıkları, Banu Öğretmen'in ise alternatif ölçme-değerlendirme yöntemlerini kullanmasına rağmen öğrencilerin puanlama sistemine aktarmada çekimser kaldığı anlaşıımıştır. Banu Öğretmen'in alternatif ölçme-değerlendirme yöntemlerini kullanmaya istekli olmasının lisans programından yeni mezun olması ve alternatif ölçme-değerlendirme yaklaşımları konusunda diğerlerine kıyasla daha çok bilgi sahibi olmasından kaynaklandığı düşünülmektedir. Bu bulgular Peker ve Gülle (2014)'nin, kıdem yılı yüksek olan matematik öğretmenlerinin alternatif ölçme ve değerlendirme yaklaşımları hakkında bilgi sahibi olmadıkları fakat kıdem yılı düşük öğretmenlerin alternatif ölçme-değerlendirme yaklaşımları konusunda daha çok bilgi sahibi oldukları sonucu ile örtüşmektedir. Ayrıca öğretmenlerin ödev takip çizelgesi oluşturdukları ve bu çizelgelere göre de öğrencileri değerlendirdiklerine dikkat edilmiştir. Benzer ve Eldem (2013) de Türkçe ve Edebiyat öğretmenlerinin ölçme ve değerlendirme araçları hakkında görüşlerini aldıkları çalışmalarında öğretmenlerin bazılarının öğrencilerin hazırbulunuşluklarını ölçerken ödev takibine dikkat ettiklerini söylemişlerdir.

Katılımcılar kendilerini ölçme-değerlendirme konusunda özellikle alternatif ölçme-değerlendirme araçlarının hazırlanması, uygulanması ve değerlendirilmesi konusunda yeterli görmemektedirler. Öğretmenler bu konuda eğitim almaya ve kendilerini geliştirmeye isteklidirler. Bu bulgular Göktaş ve Arıbaş (2014)'ın çalışmasında ulaştıkları öğretmenlerin alternatif ölçmedeğerlendirme konusunda uzman kişiler tarafından ve uygulamalı olarak verilen eğitimler almak istedikleri bulgusu ile örtüşmektedir.

Öğretmenler, ölçme ve değerlendirme ile ilgili kurs, seminer ve hizmet-içi eğitim gibi çalışmalara katılmak istediklerini belirtmiştir. Benzer şekilde, Güven (2001) de çalışmasında öğretmen ve öğretmen adaylarını ölçme-değerlendirme konusunda yetiştirebilmek için her türlü faaliyet, hizmet-içi eğitim ve seminerlerin uygulanabileceğini ve üniversitelerde derslerin niteliğini arttırmak gerektiğini belirtmiştir.

Bir başka önemli sonuç ise, katılımcıların okul yöneticileri ve zümre öğretmenleri tarafından, kullanacakları ölçmedeğerlendirme yöntemleri veya çeşitliliği açısından zorunluluk veya yönlendirme hissettikleridir. Özellikle, Banu Öğretmen, bu durumu zümresinin seçtiği yöntemden farklı bir yöntemi uygulayamadığı noktasında açıkça belirtmiştir. Bunun sebebi, Banu Öğretmen'in zümresindeki diğer öğretmenlere göre alternatif ölçme-değerlendirme konusunda daha çok bilgi sahibi olmasına rağmen, onlardan daha az deneyimli olması, karar verme sürecinde söz sahibi olamamasından kaynaklanıyor olabilir.

Katılımcılar görüşmelerde çeşitli nedenlerle ölçme ve değerlendirme sürecinde yüksek not verme kaygısı yaşamakta olduklarını, öğrencilere hak etmeseler de yüksek notlar verdiklerini belirtmişlerdir. Bunun sebebi olarak öğretmenlerin, matematik dersinin zor ve başarılamayan bir ders olduğu algısını ortadan kaldırmak ve öğrencilerin matematiğe karşı olumlu tutum geliştirmelerini istemeleri olduğu düşünülebilir. Öğretmenler öğrencilerinin notlarını yükseltmelerinin başka bir nedeni olarak, mevcut sınav ve not sistemini göstermektedirler. Buradan hareketle devlet okulunda çalışan matematik öğretmenlerinin çeşitli sebeplerle adil bir ölçme-değerlendirme sisteminin olmadığını düşündükleri söylenebilir. Öğretmenlerin yaptıkları ölçme-değerlendirme uygulamalarının ve not verme biçimlerinin öğrencilerin mevcut başarı düzeylerini ve öğrenme eksiklerini ortaya koymada yetersiz olduğu görülmektedir.

Geliştirilen ve yenilenen ortaokul matematik programının özellikle ölçme ve değerlendirme boyutunda öğretmenlere ölçme ve değerlendirme çalışmalarını planlamada yeterince yol göstermediği, programda ölçme ve değerlendirme amaçlarına yer verildiği ancak bunların nasıl gerçekleştirileceği hakkında öğretmenlere yeterli destek verilmediği görülmüştür. Bu bulgular Duru ve Korkmaz (2010)'ın yaptıkları çalışmada matematik öğretmenleri, matematik öğretim programında ölçme-değerlendirme boyutunda yeterince etkinlik olmadığı ve programda öğretmenlere tavsiye edilen ölçme-değerlendirme uygulamalarının kalabalık sınıflarda uygulanamayacağı bulgusu ile paralellik göstermektedir. 


\section{ÖNERILER}

Çalışmamızda, öğretmenlerin çoğunlukla geleneksel ölçme-değerlendirme yöntemlerini tercih ettikleri ve alternatif yöntemleri kullanmadıkları ve hatta bunları yeterince bilmedikleri sonucuna varmış olduk. Bunun nedenleri hem lisans programlarında hem de ortaokul matematik öğretim programında alternatif ölçme-değerlendirme yöntemleri ve uygulanışı hakkında öğretmenlere yeterli bilgi verilmemesi, öğretmenlik uygulaması derslerinde etkili rehberlik edilmemesi veya hizmet-içi eğitim faaliyetlerinin yetersiz olması şeklinde sıralanabilir. Bu doğrultuda, aşağıdaki öneriler verilebilir;

1. Yapılandırmacı yaklaşım çerçevesinde yenilenen ortaokul matematik öğretim programının, aynı çerçevede alternatif ölçme ve değerlendirme yaklaşımı konusunda öğretmenler için daha geniş ve yol gösterici açıklamalarda bulunması beklenmektedir. Öğretmenlerin sınıf ortamında uygulayabilecekleri alternatif ölçme-değerlendirme uygulamalarına matematik öğretim programında yer verilebilir.

2. Yapılandırmacı yaklaşım çerçevesinde güncellenen programlara paralel olarak yapılandırmacı ölçme ve değerlendirme yaklaşımlarının öğretmenlerce kullanılabilmesi için mevcut eğitim ortam ve şartlarında düzenlemelere gidilebilir.

3. Öğretmenlere yönelik alternatif ölçme ve değerlendirme yaklaşımları ile ilgili olarak üniversiteler ve MEB'in ortak iş birliği ile uzmanlar tarafından uygulamalı hizmet-içi eğitimler ve kurslar düzenlenebilir. Çalışmamızda ortaya koyduğumuz sonuçlardan biri, öğretmenlerin ölçme-değerlendirme yöntemlerini seçerken okul yöneticileri veya zümre öğretmenleri tarafından yönlendirme hissediyor olmalarıydı. Bu nedenle, bu eğitimlere okul yöneticileri de davet edilebilir.

4. Üniversitelerde hizmet öncesi eğitim kapsamında 'ölçme ve değerlendirme' dersine ek olarak 'alternatif ölçmedeğerlendirme' yöntemleri dersi açılabilir ya da mevcut olan dersin içeriği bu anlamda geliştirilebilir.

5. Öğretmen adaylarının lisans dönemlerinde katıldıkları okul deneyimi ve öğretmenlik uygulaması dersleri alternatif ölçmedeğerlendirme yöntemleri hakkında bilgi verecek şekilde yeniden düzenlenebilir. MEB ortaklığında yürütülen bu derslerde, öğrencilere danışmanlık eden uygulayıcı öğretmenlerin alternatif ölçme-değerlendirme yöntemleri konusunda bilgi sahibi olmalarına dikkat edilebilir.

\section{KAYNAKÇA}

Bal, A. P. ve Doğanay, A. (2010). İlköğretim beşinci sınıf matematik öğretiminde ölçme-değerlendirme sürecinde yaşanan sorunların analizi. Kuram ve Uygulamada Eğitim Yönetimi Dergisi, 16(3), 373-398.

Benzer, A. ve Eldem, E. (2013). Türkçe ve edebiyat öğretmenlerinin ölçme ve değerlendirme araçları hakkında bilgi düzeyleri. Kastamonu Eğitim Dergisi, 21(2), 649-664.

Büyüktokatlı, N. ve Bayraktar, Ş. (2014). Fen eğitiminde alternatif ölçme-değerlendirme uygulamaları [Alternative Assessment Practices in Science]. Pegem Journal of Education \& Instruction, 4(1), 103-106. DOI: 10.14527/pegegog.2014.006

Creswell, J. W. (2018). Nitel araştırma yöntemleri. (M. Bütün ve S. B. Demir, Çev.). Ankara: Siyasal Kitabevi.

Duru, A. ve Korkmaz, H. (2010). Öğretmenlerin yeni matematik programı hakkındaki görüşleri ve program değişim sürecinde karşılaşılan zorluklar. Hacettepe Üniversitesi Eğitim Fakültesi Dergisi, 38(38), 67-81.

Fetterman, D. M. (2010). Ethnography: Step by step (3rd ed.). Thousand Oaks, CA: Sage.

Fourie, I., ve Van Niekerk, D. (2001). Follow-up on the use of portfolio assessment for a module in research information skills: An analysis of its value. Education for information, 19(2), 107-126.

Gelbal, S. ve Kelecioğlu, H. (2007). Öğretmenlerin ölçme-değerlendirme yöntemleri hakkındaki yeterlik algıları ve karşılaştıkları sorunlar. Hacettepe Üniversitesi Eğitim Fakültesi Dergisi, 33, 135-145.

Göktaş, Ö. ve Arıbaş, S. (2014). Ortaokul matematik dersi öğretmenlerinin hizmet içi eğitime ve alternatif ölçme-değerlendirmeye yönelik hizmet içi eğitim ihtiyaçlarına ilişkin görüşleri. Adıyaman Üniversitesi Sosyal Bilimler Enstitüsü Dergisi, 7(16), 17-42. DOI: 10.14520/adyusbd.589

Güven, S. (2001). Sınıf öğretmenlerin Ölçme ve Değerlendirmede Kullandıkları Yöntem ve Tekniklerin Belirlenmesi. X. Ulusal Eğitim Bilimleri Kongresi (Haziran 2001) Bildiri Kitabı, (ss. 413-423), Bolu: Abant İzzet Baysal Üniversitesi.

Karamustafaoğlu, S., Çağlak, A. ve Meşeci, B. (2012). Alternatif ölçme-değerlendirme araçlarına ilişkin sınıf öğretmenlerinin öz yeterlilikleri. Amasya Üniversitesi Eğitim Fakültesi Dergisi, 1(2), 167-179.

Kuran, K. ve Kanatlı, F. (2009). Alternatif ölçme-değerlendirme teknikleri konusunda sınıf öğretmenlerinin görüşlerinin değerlendirilmesi. Mustafa Kemal Üniversitesi Sosyal Bilimler Enstitüsü Dergisi, 6(12), 209-234.

Malatyalı, E. ve Yılmaz, K. (2010). Yapılandırmacı öğrenme sürecinde kavramlar ve önemi: Kavramların pedagojik açıdan incelenmesi. Uluslararası Sosyal Araştırmalar Dergisi, 3(14), 320-332.

McAlister, B. (2000). The authenticity of authentic assessment: What the research says... and doesn't say. R. Custer (Ed.). Using authentic assessment in vocational education. (ERIC Information Series No. 381, pp. 19-31). Columbus, OH: ERIC Clearinghouse on Adult, Career, and Vocational Education.

Miles, M. B. ve Huberman, A. M. (1994). Qualitative data analysis: A sourcebook of new methods (2nd ed.). Thousand Oaks, CA: Sage.

Milli Eğitim Bakanlığı. (2014). Milli Eğitim Bakanlığı Okul Öncesi Eğitim ve İlköğretim Kurumları Yönetmeliği.

Milli Eğitim Bakanlığı. (2017). Öğretmenlik Mesleği Genel Yeterlilikleri. https://oygm.meb.gov.tr/www/ogretmenlik-meslegi-genelyeterlikleri/icerik/39 adresinden 15.11.2018 tarihinde erişilmiştir.

Milli Eğitim Bakanlığı. (2018). Matematik Dersi Öğretim Programı. Ankara: MEB Yayınları. 
Mintah, J. K. (2003). Authentic assessment in physical education: Prevalence of use and perceived impact on students' self-concept, motivation, and skill achievement. Measurement in physical education and exercise science, 7(3), 161-174.

Nazlıçiçek, N. ve Akarsu, F. (2008). Fizik, kimya ve matematik öğretmenlerinin değerlendirme araçlarıyla ilgili yaklaşımları ve uygulamaları. Eğitim ve Bilim, 33(149), 18-29.

Patton, M. Q. (2014). Nitel araştırma ve değerlendirme yöntemleri. (M. Bütün ve S. B. Demir, Çev.). Ankara: Pegem Akademi.

Peker, M. ve Gülle, M. (2014). Matematik öğretmenlerinin yeni matematik öğretim programında yer alan ölçme araçları hakkındaki bilgi düzeyleri ve bu ölçme araçlarını kullanma sıklıkları. Illköğretim Online, 10(2), 703-716.

Şaşmaz Ören, F., Ormancı, Ü. ve Evrekli, E. (2011). Fen ve teknoloji öğretmen adaylarının alternatif ölçme-değerlendirme yaklaşımlarına yönelik öz-yeterlilik düzeyleri ve görüşleri. Kuram ve Uygulamada Eğitim Bilimleri, 11(3), 1675-1698.

Turgut, P. (2011). Ülkemizde Ölçme ve Değerlendirmenin Dünü - Bugünü ve Yarını - Dünü. Eğitimde ve Psikolojide Ölçme ve Değerlendirme Dergisi, 2(0).

Van de Walle, J. A. (2007). Elementary and Middle School Mathematics: Teaching Developmentally (Sixth edition). Boston: Pearson

Watt, H. G. M. (2005). Attitudes to the use of alternative assessment methods in mathematics: A study with secondary mathematics teachers in Sydney, Australia. Educational Studies in Mathematics, 58(1), 21-44.

Yazıcı, F. ve Sözbilir, M. (2016). Illköğretim 6-8. sınıf öğretmenlerinin ölçme-değerlendirme yöntemlerine bakış açıları, kullanım kriterleri ve karşılaştıkları problemler: Erzurum örneklemi. MSKU Eğitim Fakültesi Dergisi, 3(1), 75-93.

Yenice, N., Özden, B. ve Alpak Tunç, G. (2017). Öğretmen adaylarının alternatif ölçme ve değerlendirme yaklaşımlarını kullanmaya yönelik öz yeterliklerinin incelenmesi. Amasya Üniversitesi Eğitim Fakültesi Dergisi, 6(2), 367-397.

Yin, R. K. (2017). Durum çalışması araştırması uygulamaları. (i. Günbayı, Çev.). Ankara: Nobel Akademik Yayıncılık. 